\title{
Haploid and Doubled Haploid Techniques in Perennial Ryegrass (Lolium perenne L.) to Advance Research and Breeding
}

\author{
Rachel F. Begheyn ${ }^{1}$, Thomas Lübberstedt ${ }^{2}$ and Bruno Studer ${ }^{1, *}$ \\ 1 Molecular Plant Breeding, Institute of Agricultural Sciences, ETH Zurich, 8092 Zurich, Switzerland; \\ rachel.begheyn@usys.ethz.ch \\ 2 Department of Agronomy, Iowa State University, 100 Osborne Drive, Ames, IA 50011, USA; \\ thomasl@iastate.edu \\ * Correspondence: bruno.studer@usys.ethz.ch; Tel.: +41-446-320-157
}

Academic Editors: John W. Forster and Kevin F. Smith

Received: 28 September 2016; Accepted: 10 November 2016; Published: 28 November 2016

\begin{abstract}
The importance of haploid and doubled haploid (DH) techniques for basic and applied research, as well as to improve the speed of genetic gain when applied in breeding programs, cannot be overstated. They have become routine tools in several major crop species, such as maize (Zea mays L.), wheat (Triticum aestivum L.), and barley (Hordeum vulgare L.). DH techniques in perennial ryegrass (Lolium perenne L.), an important forage species, have advanced to a sufficiently successful and promising stage to merit an exploration of what their further developments may bring. The exploitation of both in vitro and in vivo haploid and DH methods to (1) purge deleterious alleles from germplasm intended for breeding; (2) develop mapping populations for genetic and genomic studies; (3) simplify haplotype mapping; (4) fix transgenes and mutations for functional gene validation and molecular breeding; and (5) hybrid cultivar development are discussed. Even with the comparatively modest budgets of those active in forage crop improvement, haploid and DH techniques can be developed into powerful tools to achieve the acceleration of the speed of genetic gain needed to meet future agricultural demands.
\end{abstract}

Keywords: anther culture; doubled haploid (DH); forage crops; microspore culture; perennial ryegrass (Lolium perenne L.); plant breeding

\section{Introduction}

Biomass, produced by agriculture, is humanity's main source of food, feed, and functional materials, such as fibre for cloth, construction wood, and industrial starches. In the latter half of the previous century, our agricultural systems generated higher yields than ever before during the Green Revolution. Presently, driven by predictions of global population growth, changing environmental conditions and the claim to arable land made by the biofuel sector, it is crucial that the yields increase sharply once again [1]. A doubling of the speed of yield growth is necessary in order to be able to feed the world's population in 2050 [2]. Since the Green Revolution, however, the agricultural paradigm has changed. More output with less input, in terms of agrochemicals, fertilizers, and water, on the existing cultivated land area is the current mandate [3]. Sustainability issues, such as biodiversity conservation, maintaining ecological services, and safeguarding soil fertility should be addressed by modern agriculture in order to achieve both global food security and environmental sustainability [4].

Aside from the undesirable option of expanding the agricultural area, production increases can be achieved in two ways. Firstly, by optimizing management practices, for example through precision agriculture or increasing water and nutrient supply to marginal lands, the gap between attainable 
and actual yields may be decreased $[3,5]$. The second and generally considered most sustainable way to increase outputs is via genetic crop improvements by plant breeding, raising potential yields [6,7]. Perhaps even more importantly, plant breeding enables the integration of novel traits, which is essential in achieving yield stability in the changing climatic conditions we are facing [8]. There has, therefore, been a shift in emphasis towards breeding for crop characteristics, such as nutrient and water use efficiency, tolerance to drought or salt stress, and the ability to produce high and stable yields under sub-optimal conditions [9]. The challenge for contemporary plant breeding is to not only integrate new traits into our crops, but to accelerate the genetic gain of its breeding programs at the same time, in order to achieve a doubling in speed of yield increase.

The potential impact of haploid and doubled haploid (DH) techniques on improving the speed of genetic gain when applied in breeding programs, as well as their importance and diverse applicability in basic and applied research, cannot be overstated and has been the subject of numerous reviews [10-14]. DH techniques have been, and are being, used to accelerate the breeding programs of a range of crops, most notably maize (Zea mays L.) and barley (Hordeum vulgare L.) $[15,16]$. A plethora of in vivo and in vitro protocols exist to accommodate the widely varying degrees of response between species to DH induction [11]. Even so, a number of scientifically (Arabidopsis thaliana) and economically important species, such as tomato (Solanum lycopersicum L.), cotton (Gossypium spp.), grape (Vitis spp.), trees, and medicinals are still considered recalcitrant [14].

This review aims to illustrate the importance of allocating time and resources towards further developing the efficiency and efficacy of haploid and DH techniques for forage crop breeding. In forage-based agriculture, to which close to $70 \%$ of the world's agricultural land is devoted (FAOstat, 2013), the challenges described above are no less pressing [17]. This extensive area is not only at the basis of global meat and milk production, but also plays a major role in ecosystem processes, such as nutrient cycling and carbon sequestration, as well as being a reservoir for the preservation of biodiversity [18]. Technologies, such as DH induction, can play a key role in accelerating breeding of forages, which we will illustrate using the economically important crop perennial ryegrass (Lolium perenne L.) as an example.

\section{Haploids and Doubled Haploids: Their Production and Use in Breeding and Research}

Haploids are defined as plants with a single chromosome set $(n)$ and DHs as $100 \%$ homozygous individuals stemming from chromosome doubled haploids $(2 n)$. The preferred method for the production of haploid or DH plants differs per species and depends on protocol availability, as well as efficiency in terms of investments and yields. Immature microspores, which are abundant in most flowering plants, can be induced to develop into embryos and, subsequently, into plants in vitro (androgenesis) $[19,20]$. Isolated microspore culture (IMC), although technically more challenging, is preferred over anther culture (AC) because of its higher efficiency [19] and has been routine in barley, tobacco (Nicotiana tabacum L.) and rapeseed (Brassica napus L.) breeding for some time [14]. Response to in vitro DH induction is highly genotype-dependent and colchicine may be needed for chromosome doubling [11]. Additionally, factors such as donor plant growing conditions, stress pre-treatment, medium composition and culture conditions all influence the embryo induction rates, number of regenerated plants and, especially in Poaceae species, the ratio between green and albino regenerants [11,21-23]. After roughly 50 years of research into DH induction methods it must be concluded that there probably is no single 'master switch' to stimulate the formation of embryos from any species of microspore [20]. Successful protocols, therefore, differ significantly between, and even within, species or are not yet available at all [24-26].

Haploid seed production can be induced in vivo by using irradiated or heat-treated non-functional pollen, pollen of distantly related species followed by uniparental genome elimination (wide hybridization), or pollen from haploid inducer genotypes [13]. DH wheat (Triticum aestivum L.) plants, for example, can be efficiently produced via wide crosses with maize, embryo rescue, and chemical chromosome duplication [27]. In hybrid maize breeding, haploid inducer lines are routinely 
used to obtain an average of $10 \%$ haploid kernels on the seed parent. The resulting haploid seedlings are treated with colchicine to obtain DHs [16]. Ovule culture (gynogenesis) is mainly used in species recalcitrant to androgenesis, since its efficiency is much lower due to the smaller number of ovules available per flower. The value of the $\mathrm{DH}$ can make gynogenesis an economical option, however, for example in sugar beet (Beta vulgaris L.), onion (Allium cepa L.), and some tree species [28].

Haploid and DH technologies have found wide application, especially in the field of plant breeding, for those crops where protocols are sufficiently effective [29]. Major reductions in the time needed for cultivar development have been realized, since the availability of DHs eliminates the need for the 5-7 generations of selfing traditionally required to produce inbred lines [14]. In combination with marker assisted selection (MAS), DH induction has significantly increased the efficiency of backcross breeding [30]. By applying $\mathrm{DH}$ induction to one of the early backcross generations, genotypes carrying the trait to be introgressed, as well as having the highest possible proportion of the elite genome, can be selected quickly. DHs have been released directly as cultivars in barley [31], rice (Oryza sativa L.) [32], rapeseed [33], wheat [27], and other crops, or used as parents of $\mathrm{F}_{1}$ hybrids of vegetables and maize [16], in order to benefit from hybrid vigour (heterosis) [34,35]. In ornamental breeding, haploid plants have commercial value of their own because of their smaller size compared to diploids [36].

Furthermore, DH populations have been invaluable for QTL discovery, especially in cereals, since their immortality enables robust phenotyping data to be gathered in different locations and over several years [37]. In outcrossers, which suffer from inbreeding depression, using at least one DH parent to create mapping populations has been effective [10]. Genome sequencing studies have used haploids or DHs to reduce the complexity of assembly, for example in peach (Prunus persica), citrus (Citrus spp.), coffee (Coffea spp.), apple (Malus pumila), and pear (Pyrus spp.) [13]. Microspores of tobacco, rapeseed, wheat, and barley are exploited in transformation and mutagenesis programs, in order to fix mutations and transgenes in a single step through subsequent DH induction [38-42]. For example in Brassicas, microspore mutation studies have enabled modifications of disease resistance, cold tolerance, and fatty acid composition [43]. Additionally, in vitro microspore culture systems have allowed for detailed study of embryogenesis, early cell fate decisions, embryogenesis, and totipotency [44-46]. All of these applications of haploid and DH techniques, as well as many others not mentioned here, could confer the same benefits to perennial ryegrass breeding and research as they have done, and currently do, in species for which effective and efficient DH induction protocols are available [14].

\section{Perennial Ryegrass}

\subsection{Perennial Ryegrass Breeding}

Perennial ryegrass, the economically most significant forage grass worldwide, is popular for its good yields, high digestibility for animals, and excellent grazing tolerance. Natural populations are diploid $(2 n=2 x=14)$ but both diploid and artificially-created tetraploid cultivars are available. Compared to diploids, tetraploid plants are larger, have a higher nutritive value for animals and better abiotic and biotic stress tolerances, but reduced sward density and lower persistence [47-49]. In contrast to the thousands of years of breeding effort in annual grasses, such as wheat, barley, and rice, perennial grass breeding is not even a century old [50]. Nevertheless, important improvements in yield potential, persistency and disease resistance, as well as feeding value-through increased water-soluble carbohydrate content, for example—have been achieved [51,52]. The allogamous nature of this species, due to its highly effective gametophytic self-incompatibility system [53], has, until now, restricted breeding to the population level, resulting in marked genetic diversity and heterozygosity within cultivars [54]. Modern perennial ryegrass varieties are synthetic populations, selected from the progeny of a polycross between elite genotypes, obtained by recurrent selection, with a good agronomical performance [50]. As a consequence, genes governing key agricultural traits are rarely completely fixed and cultivar characterization for variety registration purposes is complicated [55]. 
Compared to cereal grain yield increases, perennial ryegrass yield gains have been described as low [52]. Commonly cited causes for this relatively slow progress, calculated as an increase in dry matter yield of just 3.2\% per decade [51], are (1) the longer breeding cycle of perennial forage crops; (2) the absence of a harvest index trait to facilitate partitioning of dry matter into the marketed product; (3) a lack of commercial exploitation of heterosis; (4) a focus on breeding for other traits than yield, such as resistance to crown rust (Puccinia coronata), reduced aftermath heading and early spring growth [56]. In effect, the modest yield increases in perennial ryegrass are most likely due to constraints stemming from life history traits and the techniques available to forage breeders rather than physiological limitations or lack of genetic variation [51]. If genetic gains are to be improved, it is, therefore, imperative to expand the arsenal of breeding tools, as well as to find ways of working with, or around, the characteristic life cycle of perennial ryegrass. As has been shown in other crops, $\mathrm{DH}$ techniques have excellent credentials to help address both of these challenges [14].

\subsection{Doubled Haploids in Perennial Ryegrass}

Perennial ryegrass DH production through AC (Figure 1) was first attempted in the late 1970s. Initially, only embryos and albino plants were obtained, until the first green regenerants were reported in 1984 [57]. During the following decades, contemporary protocols for barley [58] and wheat [59] AC were adapted for use in perennial ryegrass by optimizing the pre-culture temperature stress, in vitro carbohydrate source, growth regulator additions, and culture conditions, such as light and temperature [58,60-62]. The total number of regenerated plants was thus increased, although the percentage of albinos remained high and genotypes capable of producing green plants by androgenesis were described as being rare exceptions [59,63]. For example, only 71 out of 229 genotypes, derived from 15 cultivars, produced regenerants after $\mathrm{DH}$ induction, and only one genotype produced green plants [64]. Only one study recounts green plant regeneration via IMC in perennial ryegrass, while in vitro gynogenesis or in vivo haploids have never been reported [65].

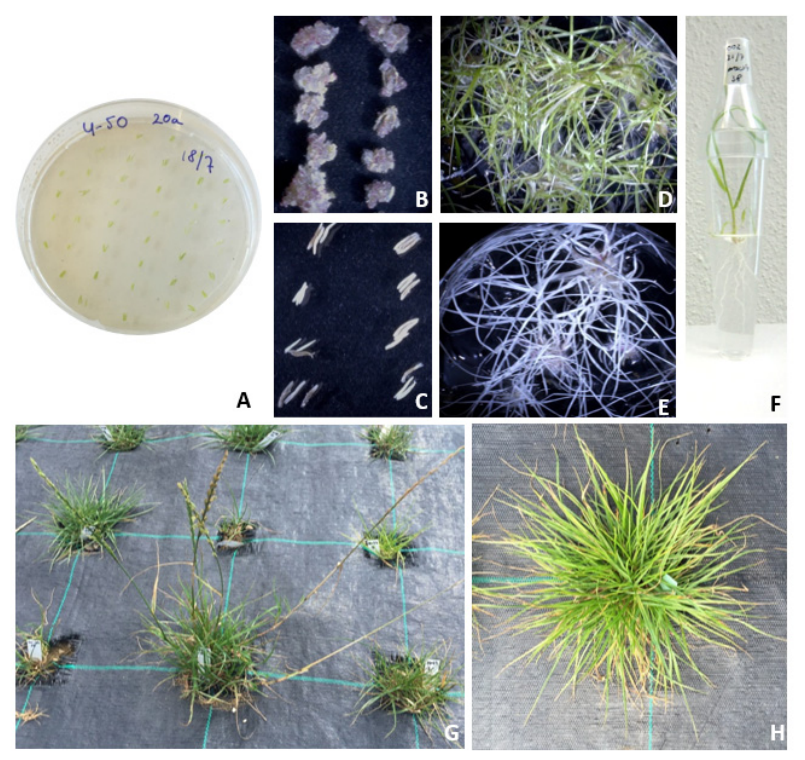

Figure 1. Different stages of perennial ryegrass (Lolium perenne L.) anther culture (AC) and doubled haploid (DH) production. (A) Fresh anthers on DH induction medium; (B) anthers of a responsive donor genotype producing many embryo-like structures (ELS) on DH induction medium, six weeks post AC; (C) anthers of an unresponsive donor genotype, six weeks post AC; (D) green and albino putative DH plantlets growing from ELS cultured on DH regeneration medium, four weeks post subculture; (E) albino plantlets growing from ELS, four weeks post subculture; (F) putative DH plantlet on regeneration medium; (G) flowering DH plant in the field; and (H) a vigorous vegetative DH plant in the field (photographs by Begheyn, R. F.). 
As in other crops, the ability to (1) form embryos or embryo-like structures (ELS); (2) regenerate plants; and (3) the ratio of green and albino regenerants, is under genetic control in perennial ryegrass $[59,61,63,66]$. Anther donor genotype was found to determine $73 \%$ of the variation in embryo yield [59] and $80 \%$ of the variation in green plant production [63]. Evidence of transgressive segregation was reported when a $60 \%$ higher green plant yield, up to 59 green plants per 100 anthers, was observed in the progeny of crosses between three genotypes responsive to AC $[66,67]$. Based on these results, Halberg et al. proposed the so-called 'inducer approach': introducing the ability to produce high numbers of green plants into recalcitrant germplasm by crosses with genotypes exhibiting that ability (the inducers; not to be confused with in vivo haploid inducers) [66]. Evidence for the efficacy of the inducer approach was reported by Madsen et al., who achieved a 7.3-fold increase in green plant yield in crosses between inducers and regular breeding germplasm [63]. The inducer approach was also effective in darnel ryegrass (L. temulentum L.) where, using an adapted perennial ryegrass AC protocol, a higher responsiveness was achieved through intercrossing good responders [68].

Androgenic capacity is recessively inherited in perennial ryegrass and probably controlled by a relatively small number of genes with a large effect [63], similar to what is supposed to be the case in barley [69]. The ability to develop ELS seems to be controlled by additive gene effects, while total plant regeneration capacity and green plant percentage seem to be controlled by dominance [67]. There may be different genes with epistatic interactions affecting green and albino plant production (as was found in wheat, [70]). However, since it has been hypothesised that in vitro conditions cause the mutations that lead to plastid development defects, albinism rates are likely to be influenced more by environment than by genetics $[67,71]$. To date, no QTL studies on androgenetic capacity in perennial ryegrass have been published. In the cereals, a limited number of reports exist, typically finding between 1 and 8 QTL for each component trait, explaining 3\%-65\% of the variation [72]. For example, two QTL, explaining $53 \%$ of the variation in green plant regeneration, were recently found in wheat [73]. In a triticale $(\times$ Triticosecale $)$ QTL study on androgenic responsiveness, 28 QTL on five chromosomes were found, explaining $5 \%-22 \%$ of the phenotypic variation [74].

Relatively high spontaneous chromosome doubling rates, between $50 \%$ and $80 \%$, are common in perennial ryegrass AC $[59,61,66,75]$. Colchicine, a toxic chromosome doubling agent, is, therefore, usually not applied, making the whole procedure safe for human health [76]. Isozyme pattern characterization studies have confirmed that nearly all diploid regenerants are, in fact, homozygous. Andersen et al., for example, reported that only three out of 913 anther-derived plants were heterozygous [65]. Non-diploid regenerants are mostly haploids, but also include a small percentage of homozygous polyploids. Apart from ploidy level, confirmation of homozygosity and reports of obvious signs of inbreeding depression, there is a marked lack of information on the performance of the DH plants. One field study compared the biomass and seed yields of DH lines and their parents, finding reductions of 80 and over $90 \%$, respectively [77]. A different field trial evaluated seed set in $75 \mathrm{DH}$ lines selected for their vigorous growth and found a $70 \%$ lower performance compared to their parents [65]. Nevertheless, one DH clone produced $5.08 \mathrm{~g}$ seeds/plant compared to the $1.44 \mathrm{~g}$ of its parent, suggesting that it is possible to identify $\mathrm{DH}$ plants with both vigorous growth and excellent fertility. Self-fertility of DH plants was investigated in a study by Madsen et al. and their seed set was found to be very low at $0-0.4$ seeds per spike [78].

\section{Future Applications of Haploid and Doubled Haploid Techniques in Perennial Ryegrass}

Strategies to accelerate perennial ryegrass breeding in order to increase yield gains have been, and are being, discussed [56,79-82], but the role that DH techniques could play in this context has hardly ever been considered. DH techniques have the potential to help unlock and increase the genetic variation available for selection, as well, as facilitate the development of more rapid and efficient selection and breeding procedures [83]. An effective perennial ryegrass AC protocol is available; however, transitioning to IMC would certainly increase efficiency and yield even further. Major leaps in efficiency are likely to be achievable for both methods, since adaptations which increase the yields 
of already highly successful protocols continue to be published regularly $[11,84,85]$. Only this year for example, a two- to four-fold increase in the number of embryos and regenerated plants in both barley and wheat was reported, achieved through the addition of dimethyl sulfoxide (DMSO) to the pre-treatment medium [86].

In vivo haploid induction has never been reported in perennial ryegrass even though, due to low genotypic specificity and relatively simple technical demands, it could prove highly practical. Additionally, segregation distortion due to in vitro androgenesis, resulting in higher allele frequencies of the donor most amenable to tissue culture, can thus be avoided [29,87-91]. Recently, two DH inducer lines of annual ryegrass (L. perenne L. subsp. multiflorum (Lam.) Husnot [syn. L. multiflorum Lam.]) have been registered which, when crossed with tall fescue (L. arundinaceum (Schreb.) Darbysh. [syn. Festuca arundinacea Schreb.]), produce $\mathrm{F}_{1}$ hybrids that can yield low percentages of both tall fescue and annual ryegrass $\mathrm{DHs}$ [92]. Selection could be performed on the vigorous $\mathrm{F}_{1}$ hybrids prior to inflorescence harvest and the subsequent recovery of 1-5 DHs per plant [93]. Perhaps this technique could be applied to perennial ryegrass as well. Alternatively, it might be worthwhile to investigate the existence of perennial ryegrass haploid inducing genes, such as CENH3 discovered in Arabidopsis [94], which seems to also affect centromere disruption and genome elimination in maize [95], barley, and sugar beet [96].

Dwivedi et al. have recently published a comprehensive review of the myriad applications of DHs in plant breeding and research [14], many of which may be applicable in perennial ryegrass as well. However, it is important to realize that the costs associated with the implementation of the DH applications which have been proposed, or indeed are already applied elsewhere, may be prohibitive in a forage crop. The significantly lower economic value of perennial ryegrass compared to crops, such as maize, barley, and rice, limits the available resources for using and further developing DH techniques. Nevertheless, there definitely are exciting possibilities for exploiting DHs within the budgetary reach of perennial ryegrass researchers and breeders, some of which will be highlighted in this section.

\subsection{Purging Deleterious Alleles}

Recessive deleterious mutations are thought to play a major role in inbreeding depression, which is observed when allogamous species, such as perennial ryegrass, are selfed [97]. Such recessive alleles are masked in heterozygous genotypes, but are carried at one or more loci in a majority of gametes. To purge deleterious alleles from germplasm intended for breeding, $\mathrm{DH}$ induction has been proposed as the most effective method. By fixing maize landraces as DH lines, the genetic basis of elite maize germplasm could be broadened [98]. In one field study, for example, genetically highly diverse and distant lines with a grain yield similar to elite lines could be selected [99]. The introgression of interesting traits from landraces without incurring yield impairments is thus enabled by using a $\mathrm{DH}$ selection phase. Introgression breeding is commonly practiced in the Lolium-Festuca complex as well, for example, to improve winter hardiness, crown rust resistance, and drought tolerance [52]. A recent study revealed extensive genetic variation in European ecotypes of perennial ryegrass, much of which has not yet been exploited in modern cultivars [54]. Germplasm intended for population and synthetics breeding can benefit from the inclusion of a DH step to reduce deleterious genetic load. Given the status of DH techniques in perennial ryegrass, purging deleterious alleles from natural populations for introgression breeding is not feasible using current in vitro methods. The development of an in vivo haploid induction system would be exceedingly useful for work with natural populations of the Lolium-Festuca complex.

\subsection{Doubled Haploids for Genetics and Genomics}

To accelerate perennial ryegrass breeding, increased knowledge on the genetics underlying traits of interest allows for a more informed and, thus, effective selection process to exploit available genetic variation. DH technologies can significantly reduce the time and costs required for genomics and 
genetics studies of perennial ryegrass, as it has done in other crops $[13,14]$. Since the existing DH induction procedure is not yet successful in all genotypes, it may be sensible to restrict some of the methods proposed in the following section to a few 'model genotypes' at this time. These genotypes should be selected for their ability to produce large numbers of green, chromosome-doubled, vigorous and fertile DHs. Similar to the highly androgenetic barley cultivar 'Igri' [39,89,100-102], such model genotypes may yield a wealth of information which can then be used in perennial ryegrass breeding.

\subsubsection{Transformation and Mutation}

An efficient transformation system is an important tool for functional gene validation and molecular breeding. Protocols to transform (embryogenic) calli using Agrobacterium, particle bombardment, and electroporation have been published and successfully used in perennial ryegrass (reviewed in [103]), although problematically low regeneration efficiencies are often reported. Additionally, it is challenging to perform the selfings needed in order to fix a transgene for further evaluation in this SI species. In vitro or in vivo microspore transformation, either by Agrobacterium, particle bombardment or cell-penetrating peptides (CPPs), and subsequent DH induction and regeneration can overcome both these issues [104]. Agrobacterium-mediated transformation was successfully used in concert with IMC in barley and resulted in single-copy [39] and even transcription activator-like effector nuclease (TALEN)-mediated gene knock-out DH transformants [102]. Similar successes were reported in other crops, such as wheat [38] and rapeseed [33]. Linear DNA, enzymes, and proteins could be delivered into triticale [105] and wheat [106] microspores by CPPs. These types of peptides can thus be used for both transformation and transgene-free genome editing, if for example proteins and guide RNAs of the CRISPR/Cas system are introduced [107].

Mutation techniques combine well with DH technology, because, as with transgene approaches, homozygous and stable integration of (recessive) mutations does not require additional generations of selfing [108]. Additionally, DHs or their microspores are excellent targets for mutagenesis since the absence of background variation in their genomes allows for easy identification of mutants. Both seeds derived from DHs, as well as haploid microspores, have been mutagenized in a range of crop species, such as wheat, barley, and rice [109]. A number of microspore mutagenesis studies have been performed to target oil quality characteristics in several Brassica species and significant diversity could be induced for these traits [43]. The detection of false-positives can be prevented by using DH starting material for TILLING experiments, a technique that has recently received attention to advance forage grass breeding [79]. In barley, seeds of a DH line were used for a TILLING experiment [110], however, DH derived microspores would be a better target in perennial ryegrass in order to circumvent the need for selfing.

Combining mutagenesis and transformation studies with DH techniques significantly reduces the time and costs required to obtain modified homozygotes for genotype-phenotype validation, as well as generate and fixate genetic variation [42]. Markedly smaller populations are required to obtain genotypes with multiple homozygous transgene inserts or mutations when DH induction is used instead of self-fertilization [111]. Considerable reductions in space can be gained if the selection of regenerants can be done during the in vitro stage. Small tissue samples for DNA extraction and further analysis may be taken from in vitro cultures, for example, to detect genotypes with modifications to the gene of interest in reverse genetics screens. Alternatively, a selection agent, such as $\mathrm{NaCl}$ or a pathogen-derived substance, can be added to the culture medium after mutagenesis, in order to obtain DH mutants with tolerances to certain stresses [10].

\subsubsection{Population Development for Mapping}

Chromosome maps as well as a vast number of mapped genetic markers have been established through DH techniques in a range of species, such as rapeseed [112], wheat [113], and barley [114]. Indeed, the genetic map of the International Lolium Genome Initiative (ILGI) was constructed from a cross between a DH and a heterozygous perennial ryegrass genotype $[115,116]$. Segregating DH 
populations provide excellent opportunities to find marker-trait associations through linkage mapping and have been extensively used in many crops [117]. Tuvesson et al. describe how a DH mapping population for marker-trait associations can be created and maintained in rye, a crop which, like perennial ryegrass, suffers from inbreeding depression [30]. Two distinct DHs are used to produce an $\mathrm{F}_{1}$ population, individuals of which are then subjected to DH induction. Both the parental DHs and the $\mathrm{F}_{1}$-derived $\mathrm{DHs}$ are crossed to a tester in order to keep them alive. Lolium-Festuca hybrids exhibit high levels of recombination within their gametes and thus offer unique opportunities to determine genome organization, elucidate genetic control of key agricultural traits and map markers [118]. Such introgression mapping combines well with DH induction and this approach has already been successfully used to obtain and select useful gene combinations for freezing-tolerance [119].

Inducing a large number of DHs from a single, highly heterogeneous genotype could circumvent the construction of a designed population altogether and allow for direct haplotype mapping (Figure 2). Every single microspore-derived plant is a unique product of recombination between the chromosomal pairs of the donor and an analysis of the inheritance of markers and genes is, therefore, possible in such a population. Single pollen grain PCR-based sequencing methods for recombination studies have been described in barley, maize, sorghum, and other crops [120-122]. However, a major advantage of DH induction over these approaches is that it allows for phenotyping, in addition to genotyping. Additionally, a sufficiently high number of DHs can be regenerated from the microspores of a single plant to allow for fine-mapping or even map-based cloning approaches, without being dependent on the seed set of specific crosses.

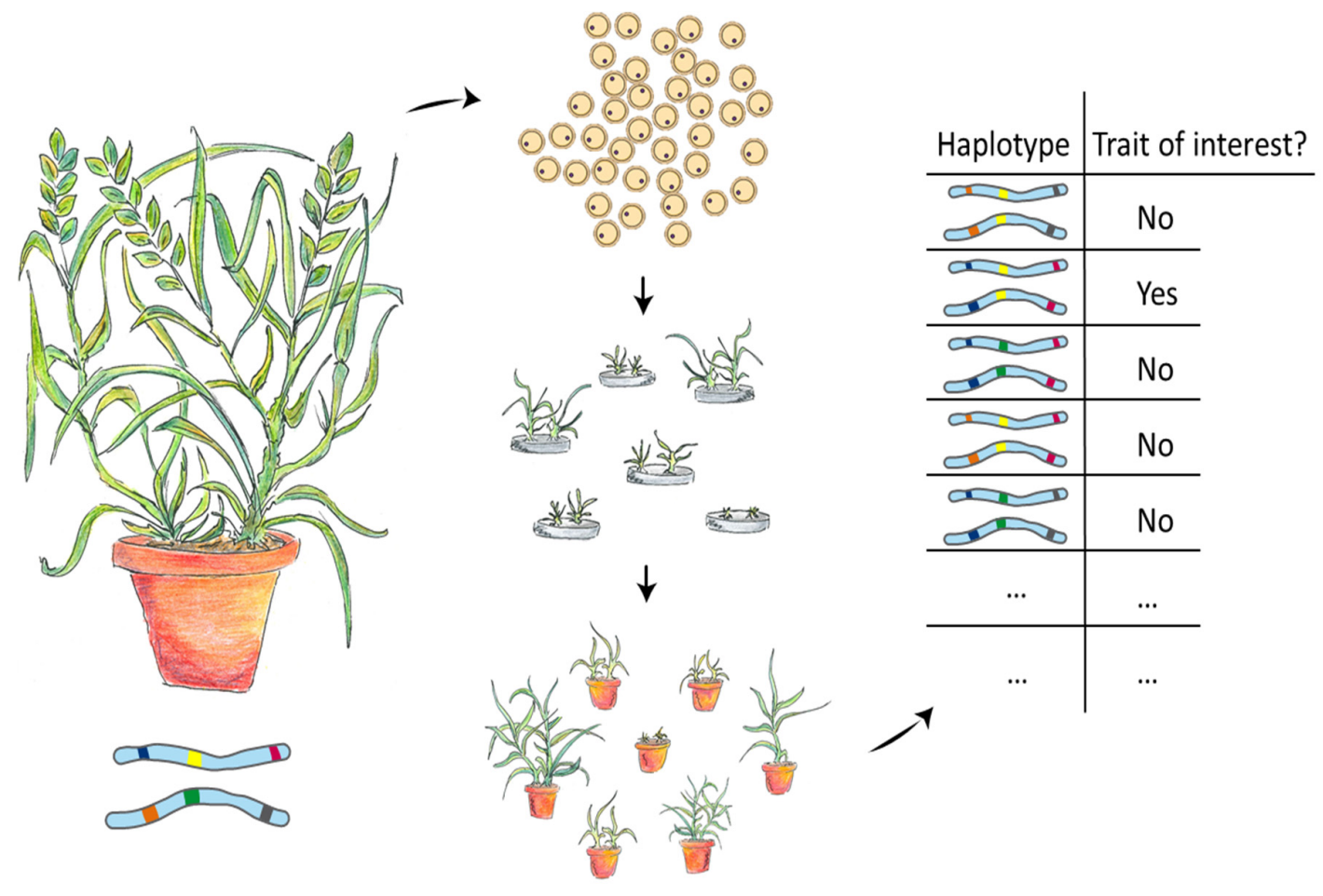

Figure 2. Schematic representation of a direct haplotype mapping strategy by $\mathrm{DH}$ induction of microspores derived from a single, heterozygous genotype exhibiting a trait of interest. Through recombination during meiosis in the donor plant, the microspore population represents a large diversity of possible haplotypes. Both donor and microspore-derived DH plants are genotyped and phenotyped so that statistical methods can be used to infer the haplotype associated with the trait of interest (in this case the dark blue, yellow, and red alleles). 


\subsection{Doubled Haploids for Hybrid Breeding}

Hybrid breeding has made a significant contribution to the acceleration of yield gains of many important crops through the exploitation of the phenomenon of heterosis [123]. In perennial ryegrass, $\mathrm{DH}$ induction may well be the most practical method for the development of homozygous lines for hybrid breeding (Table 1). Currently, most breeding germplasm is recalcitrant to DH induction, necessitating the introgression of androgenic capacity $[63,66]$. Using modern mapping approaches, it should be feasible to obtain markers associated with the few major genes expected to control ELS formation and green plant regeneration [63,67], in order to accelerate their introgression into elite material [72].

Table 1. Comparison of three methods to obtain inbred or $100 \%$ homozygous lines in perennial ryegrass.

\begin{tabular}{|c|c|c|c|}
\hline & $\begin{array}{c}\text { Repeated } \\
\text { Self-Fertilization }\end{array}$ & $\begin{array}{l}\text { In Vitro Doubled } \\
\text { Haploid Induction }\end{array}$ & $\begin{array}{l}\text { In Vivo Doubled } \\
\text { Haploid Induction }\end{array}$ \\
\hline Method available & yes & yes $^{1}$ & no \\
\hline Genotype specificity & low & high & unknown \\
\hline Efficiency & low & high $^{2}$ & unknown \\
\hline Required skill & low & moderate & low ${ }^{3}$ \\
\hline Space required & high & low & high \\
\hline Lab requirements & none & high & low \\
\hline Generations required & $5-6^{4}$ & 1 & 1 \\
\hline Diploid regenerants & $100 \%$ & $50 \%-80 \%$ & unknown $^{5}$ \\
\hline Obstacles & $\begin{array}{l}\text { self-incompatibility } \\
\text { inbreeding depression }\end{array}$ & $\begin{array}{l}\text { albinism } \\
\text { inbreeding depression }\end{array}$ & inbreeding depression \\
\hline Side effects of procedure ${ }^{6}$ & $\begin{array}{l}\text { allows selection every } \\
\text { generation }\end{array}$ & $\begin{array}{l}\text { gametoclonal variation } \\
\text { somatoclonal variation } \\
\text { ploidy level variation } \\
\text { segregation distortion }\end{array}$ & $\begin{array}{l}\text { part of inducer genome } \\
\text { could integrate }\end{array}$ \\
\hline
\end{tabular}

${ }^{1}$ Anther culture, possibly isolated microspore culture; ${ }^{2}$ Up to several hundreds of plants per 100 cultured anthers using current anther culture techniques; ${ }^{3}$ High if embryo rescue is required; ${ }^{4}$ Some residual heterozygosity (theoretically $1.6 \%$ after six generations); ${ }^{5}$ If the chosen method generates haploids, colchicine will be needed to double the chromosomes; ${ }^{6}$ Can be positive or negative depending on end-use.

Even though inbreeding depression is severe in perennial ryegrass DHs, reports of vigorous and fertile plants do exist [65]. In the early days of maize [124] and rye hybrid breeding [125], both allogamous cereals suffered from inbreeding depression as well, and selection among inbred lines was successfully used to improve their vigour and fertility to economically practical levels. Similar to the purging of deleterious alleles described above, DH induction may, thus, be used as a selection tool against inbreeding depression (Niels Roulund, personal communication; [97]). Additionally, negative effects from inbreeding depression may be averted if diploid or tetraploid single-cross hybrids are used as parents to produce double-cross hybrids. Indeed, tetraploid cultivars are of special interest in the context of hybrid breeding, because polyploids often exhibit progressive heterosis the larger the genetic diversity between their component genomes is $[35,126]$. A single-cross hybrid between two homozygous autotetraploids (AABB) will display heterosis, but a double-cross hybrid from two distinct single-cross hybrids (ABCD) is nearly always more heterotic [127]. Conversely, tetraploid Lolium-Festuca hybrids have been converted into diploids by AC to reduce vigour and plant size for turf applications [128]. DH techniques can, thus, allow breeders to manipulate ploidy level and homozygosity in order to maximize the exploitation of heterosis in future perennial ryegrass cultivars.

Hybrid seed production requires efficient multiplication of inbred lines, as well as an effective method to control pollination. Elucidation of the SI system and the development of markers for its components are now within reach [129-131] and should enable maintenance and multiplication of DH lines through seed. Interestingly, repeated selfing of DHs has been proposed as a method to cause the 
breakdown of SI, since rare mutations in SI genes in pollen grains can, thus, be selected [78]. Schemes to produce $F_{1}$ seed of perennial ryegrass based on population hybridization $[50,126]$, cytoplasmic male sterility (CMS) [82,132], and SI [82,133,134] have been proposed (see also [135]), although opinions differ on which method is the most practically and economically feasible.

\section{Concluding Remarks}

$\mathrm{DH}$ techniques in perennial ryegrass have advanced to a sufficiently successful and promising stage to warrant a tentative glance at what future developments in this field may bring to both breeding and research [12]. Some exceedingly useful applications require the realization of relatively small improvements to existing in vitro protocols which could be derived from successful work in barley, rye, and wheat [86]. For example, highly androgenic genotypes may be used as models in $\mathrm{DH}$ or microspore transformation and mutagenization studies, or for direct haplotype mapping [39]. Homozygous line production for hybrid breeding, however, will require either improved in vitro protocols that are effective in recalcitrant genotypes or the introgression of androgenic capacity into breeding germplasm $[63,66]$. Additionally, investigations into and improvement of the agronomic performance of perennial ryegrass DHs, as well as an efficient seed production system, are required for an economically feasible production of hybrid cultivars. An alternative strategy to significantly reduce genotype specific responses to in vitro DH production, would be the development of in vivo haploid or DH inducers [92]. These would also allow the purging of deleterious alleles from natural populations, thus enabling a broadening of the genetic variation available for breeding without incurring high levels of performance impairment [99].

All of the haploid and DH techniques discussed here should reduce the time, space, and investment required to perform effective perennial ryegrass research and breeding. Since this species can be regarded as a model for other grasses, any progress made should be beneficial to them as well. Even with the comparatively modest budgets of those active in forage crop improvement, haploid and DH techniques can be developed into powerful tools to achieve the acceleration of the speed of genetic gain needed to meet future agricultural demands.

Acknowledgments: This work was supported by ETH Research Grant ETH-34 14-1 and the Swiss National Science Foundation (SNSF Professorship grant No.: PP00P2 138988). RFB and BS wish to express their gratitude to Niels Roulund and Kirsten Vangsgaard for their support in their work on perennial ryegrass DH induction. RFB gratefully acknowledges Léonor Bonnafous for her help with Figure 2.

Conflicts of Interest: The authors declare no conflict of interest.

\section{Abbreviations}

The following abbreviations are used in this manuscript:

AC anther culture

$\mathrm{DH}$ doubled haploid

CENH3 centromere-specific histone 3 variant

CRISPR clustered regularly interspaced short palindrome repeats

DMSO dimethyl sulfoxide

ELS embryo-like structures

IMC isolated microspore culture

MAS marker-assisted selection

QTL quantitative trait locus/loci

SI self-incompatible/self-incompatibility

TALEN transcription activator-like effector nuclease

TILLING targeting induced local lesions in genomes

\section{References}

1. Tilman, D.; Balzer, C.; Hill, J.; Befort, B.L. Global food demand and the sustainable intensification of agriculture. Proc. Natl. Acad. Sci. USA 2011, 108, 20260-20264. [CrossRef] [PubMed] 
2. Fischer, R.A.; Byerlee, D.; Edmeades, G.O. Crop Yields and Global Food Security: Will Yield Increase Continue to Feed the World? ACIAR Monograph No. 158; Australian Centre for International Agricultural Research: Canberra, Australia, 2014.

3. Foley, J.A.; Ramankutty, N.; Brauman, K.A.; Cassidy, E.S.; Gerber, J.S.; Johnston, M.; Mueller, N.D.; O'Connell, C.; Ray, D.K.; West, P.C.; et al. Solutions for a cultivated planet. Nature 2011, 478, 337-342. [CrossRef] [PubMed]

4. Brummer, C.E.; Barber, W.T.; Collier, S.M.; Cox, T.S.; Johnson, R.; Murray, S.C.; Olsen, R.T.; Pratt, R.C.; Thro, A.M. Plant breeding for harmony between agriculture and the environment. Front. Ecol. Environ. 2011, 9, 561-568. [CrossRef]

5. Fischer, R.A.; Edmeades, G.O. Breeding and cereal yield progress. Crop Sci. 2010, 50, S85-S98. [CrossRef]

6. Stamp, P.; Visser, R. The twenty-first century, the century of plant breeding. Euphytica 2012, 186, 585-591. [CrossRef]

7. Fischer, R.A. Definitions and determination of crop yield, yield gaps, and of rates of change. Field Crops Res. 2015, 182, 9-18. [CrossRef]

8. Tester, M.; Langridge, P. Breeding technologies to increase crop production in a changing world. Science 2010, 327, 818-822. [CrossRef] [PubMed]

9. Dawson, I.K.; Russell, J.; Powell, W.; Steffenson, B.; Thomas, W.T.B.; Waugh, R. Barley: A translational model for adaptation to climate change. New Phytol. 2015, 206, 913-931. [CrossRef] [PubMed]

10. Germanà, M.A. Gametic embryogenesis and haploid technology as valuable support to plant breeding. Plant Cell Rep. 2011, 30, 839-857. [CrossRef] [PubMed]

11. Seguí-Simarro, J.M. Androgenesis revisited. Bot. Rev. 2010, 76, 377-404. [CrossRef]

12. Forster, B.P.; Heberle-Bors, E.; Kasha, K.J.; Touraev, A. The resurgence of haploids in higher plants. Trends Plant Sci. 2007, 12, 368-375. [CrossRef] [PubMed]

13. Dunwell, J.M. Haploids in flowering plants: Origins and exploitation. Plant Biotechnol. J. 2010, 8, 377-424. [CrossRef] [PubMed]

14. Dwivedi, S.L.; Britt, A.B.; Tripathi, L.; Sharma, S.; Upadhyaya, H.D.; Ortiz, R. Haploids: Constraints and opportunities in plant breeding. Biotechnol. Adv. 2015, 33, 812-829. [CrossRef] [PubMed]

15. Seguí-Simarro, J.M. Editorial: Doubled haploidy in model and recalcitrant species. Front. Plant Sci. 2015, 6, 1-2. [CrossRef] [PubMed]

16. Geiger, H.H.; Gordillo, G.A. Doubled haploids in hybrid maize breeding. Maydica 2009, 54, 485-499.

17. Smith, K.F.; Spangenberg, G. Forage breeding for changing environments and production systems: An overview. Crop Pasture Sci. 2014, 65. [CrossRef]

18. Reheul, D.; De Cauwer, B.; Cougnon, M. The role of forage crops in multifunctional agriculture. In Fodder Crops and Amenity Grasses; Boller, B., Posselt, U., Veronesi, F., Eds.; Springer: New York, NY, USA, 2010; pp. 457-476.

19. Ferrie, A.M.R.; Caswell, K.L. Isolated microspore culture techniques and recent progress for haploid and doubled haploid plant production. Plant Cell Tissue Organ Cult. 2011, 104, 301-309. [CrossRef]

20. Seguí-Simarro, J.M.; Nuez, F. How microspores transform into haploid embryos: Changes associated with embryogenesis induction and microspore-derived embryogenesis. Physiol. Plant. 2008, 134, 1-12. [CrossRef] [PubMed]

21. Shariatpanahi, M.E.; Bal, U.; Heberle-Bors, E.; Touraev, A. Stresses applied for the re-programming of plant microspores towards in vitro embryogenesis. Physiol. Plant. 2006, 127, 519-534. [CrossRef]

22. Islam, S.M.S.; Tuteja, N. Enhancement of androgenesis by abiotic stress and other pretreatments in major crop species. Plant Sci. 2012, 182, 134-144. [CrossRef] [PubMed]

23. Kumari, M.; Clarke, H.J.; Small, I.; Siddique, K.H.M. Albinism in plants: A major bottleneck in wide hybridization, androgenesis and doubled haploid culture. CRC. Crit. Rev. Plant Sci. 2009, 28, 393-409. [CrossRef]

24. Maluszynski, M.; Kasha, K.J.; Forster, B.P.; Szarejko, I. Doubled Haploid Production in Crop Plants: A manual; Maluszynski, M., Kasha, K.J., Forster, B.P., Szarejko, I., Eds.; Kluwer Academic Publishers: Dordrecht, The Netherlands, 2003.

25. Touraev, A.; Forster, B.P.; Mohan Jain, S. Advances in Haploid Production in Higher Plants; Touraev, A., Forster, B.P., Jain, S.M., Eds.; Springer: Dordrecht, The Netherlands, 2009. 
26. Germanà, M.A.; Lambardi, M. In Vitro Embryogenesis in Higher Plants, 1st ed.; Germanà, M.A., Lambardi, M., Eds.; Humana Press: New York, NY, USA, 2016.

27. Niu, Z.; Jiang, A.; Abu Hammad, W.; Oladzadabbasabadi, A.; Xu, S.S.; Mergoum, M.; Elias, E.M. Review of doubled haploid production in durum and common wheat through wheat $\times$ maize hybridization. Plant Breed. 2014, 133, 313-320. [CrossRef]

28. Chen, J.-F.; Cui, L.; Malik, A.A.; Mbira, K.G. In vitro haploid and dihaploid production via unfertilized ovule culture. Plant Cell Tissue Organ Cult. 2010, 104, 311-319. [CrossRef]

29. Pink, D.; Bailey, L.; McClement, S.; Hand, P.; Mathas, E.; Buchanan-Wollaston, V.; Astley, D.; King, G.; Teakle, G. Double haploids, markers and QTL analysis in vegetable brassicas. Euphytica 2008, 164, 509-514. [CrossRef]

30. Tuvesson, S.; Dayteg, C.; Hagberg, P.; Manninen, O.; Tanhuanpää, P.; Tenhola-Roininen, T.; Kiviharju, E.; Weyen, J.; Förster, J.; Schondelmaier, J.; et al. Molecular markers and doubled haploids in European plant breeding programmes. Euphytica 2006, 158, 305-312. [CrossRef]

31. Devaux, P.; Kasha, K.J. Overview of barley doubled haploid production. In Advances in Haploid Production in Higher Plants; Touraev, A., Forster, B.P., Jain, S.M., Eds.; Springer: Dordrecht, The Netherlands, 2009; pp. 47-64.

32. Mishra, R.; Jwala, G.; Ao, N.R. In Vitro androgenesis in rice: Advantages, constraints and future prospects. Rice Sci. 2016, 23, 57-68. [CrossRef]

33. Ferrie, A.M.R.; Möllers, C. Haploids and doubled haploids in Brassica spp. for genetic and genomic research. Plant Cell Tissue Organ Cult. 2010, 104, 375-386. [CrossRef]

34. Lippman, Z.B.; Zamir, D. Heterosis: Revisiting the magic. Trends Genet. 2006, 23, 60-66. [CrossRef] [PubMed]

35. Birchler, J.A.; Yao, H.; Chudalayandi, S.; Vaiman, D.; Veitia, R.A. Heterosis. Plant Cell 2010, 22, $2105-2112$. [CrossRef] [PubMed]

36. Ferrie, A.M.R. Doubled haploidy as a tool in ornamental breeding. Acta Hortic. 2012, 953, 167-171. [CrossRef]

37. Obsa, B.T.; Eglinton, J.; Coventry, S.; March, T.; Langridge, P.; Fleury, D. Genetic analysis of developmental and adaptive traits in three doubled haploid populations of barley (Hordeum vulgare L.). Theor. Appl. Genet. 2016, 129, 1139-1151. [CrossRef] [PubMed]

38. Brew-Appiah, R.A.T.; Ankrah, N.; Liu, W.; Konzak, C.F.; Von Wettstein, D.; Rustgi, S. Generation of doubled haploid transgenic wheat lines by microspore transformation. PLoS ONE 2013, 8, e80155. [CrossRef] [PubMed]

39. Kumlehn, J.; Serazetdinova, L.; Hensel, G.; Becker, D.; Loerz, H. Genetic transformation of barley (Hordeum vulgare L.) via infection of androgenetic pollen cultures with Agrobacterium tumefaciens. Plant Biotechnol. J. 2006, 4, 251-261. [CrossRef] [PubMed]

40. Kapusi, E.; Hensel, G.; Coronado, M.J.; Broeders, S.; Marthe, C.; Otto, I.; Kumlehn, J. The elimination of a selectable marker gene in the doubled haploid progeny of co-transformed barley plants. Plant Mol. Biol. 2013, 81, 149-160. [CrossRef] [PubMed]

41. Huang, S.; Liu, Z. A new method for generation and screening of Chinese cabbage mutants using isolated microspore culturing and EMS mutagenesis. Euphytica 2016, 207, 23-33. [CrossRef]

42. Shen, Y.; Pan, G.; Lübberstedt, T. Haploid strategies for functional validation of plant genes. Trends Biotechnol. 2015, 33, 611-620. [CrossRef] [PubMed]

43. Ferrie, A.M.R.; Caswell, K.L. Applications of doubled haploidy for improving industrial oilseeds. In Industrial Oil Crops; McKeon, T.A., Hayes, D.G., Hildebrand, D.F., Weselake, R.J., Eds.; Elsevier Inc.: London, UK, 2016; pp. 359-378.

44. Soriano, M.; Li, H.; Boutilier, K. Microspore embryogenesis: Establishment of embryo identity and pattern in culture. Plant Reprod. 2013, 26, 181-196. [CrossRef] [PubMed]

45. Daghma, D.E.S.; Hensel, G.; Rutten, T.; Melzer, M.; Kumlehn, J. Cellular dynamics during early barley pollen embryogenesis revealed by time-lapse imaging. Front. Plant Sci. 2014, 5, 1-14. [CrossRef] [PubMed]

46. Seifert, F.; Bössow, S.; Kumlehn, J.; Gnad, H.; Scholten, S. Analysis of wheat microspore embryogenesis induction by transcriptome and small RNA sequencing using the highly responsive cultivar "Svilena". BMC Plant Biol. 2016, 16, 97. [CrossRef] [PubMed] 
47. Smith, K.F.; Simpson, R.J.; Culvenor, R.A.; Humphreys, M.O.; Prud'Homme, M.P.; Oram, R.N. The effects of ploidy and a phenotype conferring a high water-soluble carbohydrate concentration on carbohydrate accumulation, nutritive value and morphology of perennial ryegrass (Lolium perenne L.). J. Agric. Sci. 2001, 136, 65-74. [CrossRef]

48. Smith, K.F.; McFarlane, N.M.; Croft, V.M.; Trigg, P.J.; Kearney, G.A. The effects of ploidy and seed mass on the emergence and early vigour of perennial ryegrass (Lolium perenne L.) cultivars. Aust. J. Exp. Agric. 2003, 43, 481-486. [CrossRef]

49. Nair, R. Developing tetraploid perennial ryegrass (Lolium perenne L.) populations. N. Z. J. Agric. Res. 2004, 47, 45-49. [CrossRef]

50. Wilkins, P.W. Breeding perennial ryegrass for agriculture. Euphytica 1991, 52, 201-214. [CrossRef]

51. Sampoux, J.P.; Baudouin, P.; Bayle, B.; Béguier, V.; Bourdon, P.; Chosson, J.F.; Deneufbourg, F.; Galbrun, C.; Ghesquière, M.; Noël, D.; et al. Breeding perennial grasses for forage usage: An experimental assessment of trait changes in diploid perennial ryegrass (Lolium perenne L.) cultivars released in the last four decades. Field Crops Res. 2011, 123, 117-129. [CrossRef]

52. Humphreys, M.O. Genetic improvement of forage crops-Past, present and future. J. Agric. Sci. 2005, 143, 441-448. [CrossRef]

53. Cornish, M.A.; Hayward, M.D.; Lawrence, M.J. Self-incompatibility in ryegrass. I. Genetic control in diploid Lolium perenne L. Heredity 1979, 43, 95-106. [CrossRef]

54. Blackmore, T.; Thorogood, D.; Skøt, L.; Mcmahon, R.; Powell, W.; Hegarty, M. Germplasm dynamics: The role of ecotypic diversity in shaping the patterns of genetic variation in Lolium perenne. Sci. Rep. 2016, 6, 22603. [CrossRef] [PubMed]

55. Wang, J.; Pembleton, L.W.; Baillie, R.C.; Drayton, M.C.; Hand, M.L.; Bain, M.; Sawbridge, T.I.; Spangenberg, G.C.; Forster, J.W.; Cogan, N.O.I. Development and implementation of a multiplexed single nucleotide polymorphism genotyping tool for differentiation of ryegrass species and cultivars. Mol. Breed. 2014, 33, 435-451. [CrossRef]

56. Casler, M.D.; Brummer, E.C. Theoretical expected genetic gains for among-and-within-family selection methods in perennial forage crops. Crop Sci. 2008, 48, 890-902. [CrossRef]

57. Stanis, V.A.; Butenko, R.G. Developing viable haploid plants in anther culture of ryegrass. Dokl. Biol. Sci. 1984, 275, 249-251.

58. Boppenmeier, J.; Zuchner, S.; Foroughi-Wehr, B. Haploid production from barley yellow dwarf virus resistant clones of Lolium. Plant Breed. 1989, 103, 216-220. [CrossRef]

59. Olesen, A.; Andersen, S.B.; Due, I.K. Anther culture response in perennial ryegrass (Lolium perenne L.). Plant Breed. 1988, 101, 60-65. [CrossRef]

60. Opsahl-Ferstad, H.-G.; Bjornstad, A.; Rognli, O.A. Influence of medium and cold pretreatment on androgenetic response in Lolium perenne L. Plant Cell Rep. 1994, 13, 594-600. [CrossRef] [PubMed]

61. Bante, I.; Sonke, T.; Tandler, R.F.; van den Bruel, A.M.R.; Meyer, E.M. Anther culture of Lolium perenne and Lolium multiflorum. In The Impact of Biotechnology in Agriculture; Sangwan, R., Sangwan-Norreel, B.S., Eds.; Springer: Dordrecht, The Netherlands, 1990; pp. 105-127.

62. Creemers-Molenaar, J.; Beerepoot, L.J. In Vitro Culture and Micropropagation of Ryegrass (Lolium spp.). In High-Tech and Micropropagation III; Bajaj, Y.P.S., Ed.; Springer: Berlin/Heidelberg, Germany, 1992; Volume 19, pp. 549-575.

63. Madsen, S.; Olesen, A.; Dennis, B.; Andersen, S.B. Inheritance of anther-culture response in perennial ryegrass (Lolium perenne L.). Plant Breed. 1995, 114, 165-168. [CrossRef]

64. Hussain, S.W.; Richardson, K.; Faville, M.; Woodfield, D. Production of haploids and double haploids in annual (Lolium multiflorum) and perennial (L. perenne) ryegrass. In Proceedings of the 13th Australasian Plant Breeding Conference, Christchurch, New Zealand, 18-21 April 2006; Mercer, C.F., Ed.; pp. 531-536.

65. Andersen, S.B.; Madsen, S.; Roulund, N.; Halberg, N.; Olesen, A. Haploidy in ryegrass. In In Vritro Haploid Production in Higher Plants; Jain, S.M., Sopory, S.K., Veilleux, R.E., Eds.; Kluwer Academic Publishers: Dordrecht, The Netherlands, 1997; Volume 4, pp. 133-147.

66. Halberg, N.; Olesen, A.; Tuvesson, I.K.D.; Andersen, S.B. Genotypes of perennial ryegrass (Lolium perenne L.) with high anther-culture response through hybridization. Plant Breed. 1990, 105, 89-94. [CrossRef]

67. Opsahl-Ferstad, H.G.; Bjørnstad, N.; Rognli, O.A. Genetic control of androgenetic response in Lolium perenne L. Theor. Appl. Genet. 1994, 89, 133-138. [CrossRef] [PubMed] 
68. Wang, Z.-Y.; Ge, Y.; Mian, R.; Baker, J. Development of highly tissue culture responsive lines of Lolium temulentum by anther culture. Plant Sci. 2005, 168, 203-211. [CrossRef]

69. Chen, X.-W.; Cistué, L.; Muñoz-Amatriaín, M.; Sanz, M.; Romagosa, I.; Castillo, A.-M.; Vallés, M.-P. Genetic markers for doubled haploid response in barley. Euphytica 2006, 158, 287-294. [CrossRef]

70. Agache, S.; Bachelier, B.; De Buyser, J.; Henry, Y.; Snape, J. Genetic analysis of anther culture response in wheat using aneuploid, chromosome substitution and translocation lines. Theor. Appl. Genet. 1989, 77, 7-11. [CrossRef] [PubMed]

71. Torp, A.M.; Andersen, S.B. Albinism in microspore culture. In Advances in Haploid Production in Higher Plants; Touraev, A., Forster, B., Jain, S.M., Eds.; Springer: New York, NY, USA, 2009; pp. 155-160.

72. Bolibok, H.; Rakoczy-Trojanowska, M. Genetic mapping of QTLs for tissue-culture response in plants. Euphytica 2006, 149, 73-83. [CrossRef]

73. Nielsen, N.H.; Andersen, S.U.; Stougaard, J.; Jensen, A.; Backes, G.; Jahoor, A. Chromosomal regions associated with the in vitro culture response of wheat (Triticum aestivum L.) microspores. Plant Breed. 2015, 134, 255-263. [CrossRef]

74. Krzewska, M.; Czyczyło-Mysza, I.; Dubas, E.; Gołebiowska-Pikania, G.; Golemiec, E.; Stojałowski, S.; Chrupek, M.; Zur, I. Quantitative trait loci associated with androgenic responsiveness in triticale ( $\times$ Triticosecale Wittm.) anther culture. Plant Cell Rep. 2012, 31, 2099-2108. [CrossRef] [PubMed]

75. Begheyn, R.F.; Vangsgaard, K.; Roulund, N. Efficient doubled haploid production in perennial ryegrass (Lolium perenne L.). In Breeding in a World of Scarcity, Proceedings of the 2015 Meeting of the Section "Forage Crops and Amenity Grasses" of Eucarpia, Ghent, Belgium, 14 June 2016; Springer: Basel, Switzerland; pp. 151-155.

76. Melchinger, A.E.; Molenaar, W.S.; Mirdita, V.; Schipprack, W. Colchicine alternatives for chromosome doubling in maize haploids for doubled-haploid production. Crop Sci. 2016, 56, 559-569. [CrossRef]

77. Opsahl-Ferstad, H.G. Androgenetic Response in Grasses. I. Anther Culture in Perennial Ryegrass (Lolium perenne L.). II. Molecular Studies of Embryogenesis in Barley (Hordeum vulgare L.). Ph.D. Thesis, Agricultural University of Norway, Ås, Norway, 1993.

78. Madsen, S.; Olesen, A.; Andersen, S.B. Self-fertile doubled haploid plants of perennial ryegrass (Lolium perenne L.). Plant Breed. 1993, 110, 323-327. [CrossRef]

79. Manzanares, C.; Yates, S.; Ruckle, M.; Nay, M.; Studer, B. TILLING in forage grasses for gene discovery and breeding improvement. New Biotechnol. 2016, 33, 594-603. [CrossRef] [PubMed]

80. Conaghan, P.; Casler, M.D. A theoretical and practical analysis of the optimum breeding system for perennial ryegrass. Irish J. Agric. Sci. 2011, 50, 47-63.

81. Wang, Z.Y.; Brummer, E.C. Is genetic engineering ever going to take off in forage, turf and bioenergy crop breeding? Ann. Bot. 2012, 110, 1317-1325. [CrossRef] [PubMed]

82. Arias Aguirre, A.; Studer, B.; Frei, U.; Lübberstedt, T. Prospects for hybrid breeding in bioenergy grasses. BioEnergy Res. 2011, 5, 10-19. [CrossRef]

83. Langridge, P.; Fleury, D. Making the most of "omics" for crop breeding. Trends Biotechnol. 2011, $29,33-40$. [CrossRef] [PubMed]

84. Sinha, R.K.; Eudes, F. Dimethyl tyrosine conjugated peptide prevents oxidative damage and death of triticale and wheat microspores. Plant Cell Tissue Organ Cult. 2015, 122, 227-237. [CrossRef]

85. Sriskandarajah, S.; Sameri, M.; Lerceteau-Köhler, E.; Westerbergh, A. Increased recovery of green doubled haploid plants from barley anther culture. Crop Sci. 2015, 55, 2806-2812. [CrossRef]

86. Echavarri, B.; Cistue, L. Enhancement in androgenesis efficiency in barley (Hordeum vulgare L.) and bread wheat (Triticum aestivum L.) by the addition of dimethyl sulfoxide to the mannitol pretreatment medium. Plant Cell Tissue Organ Cult. 2016, 125, 11-22. [CrossRef]

87. Devaux, P.; Zivy, M. Protein markers for anther culturability in barley. Theor. Appl. Genet. 1994, 88, 701-706. [CrossRef] [PubMed]

88. Zhang, L.; Zhang, L.; Luo, J.; Chen, W.; Hao, M.; Liu, B.; Yan, Z.; Zhang, B.; Zhang, H.; Zheng, Y.; et al. Synthesizing double haploid hexaploid wheat populations based on a spontaneous alloploidization process. J. Genet. Genom. 2011, 38, 89-94. [CrossRef] [PubMed]

89. Muñoz-Amatriaín, M.; Castillo, A.M.; Chen, X.W.; Cistué, L.; Vallés, M.P. Identification and validation of QTLs for green plant percentage in barley (Hordeum vulgare L.) anther culture. Mol. Breed. 2008, 22, 119-129. [CrossRef] 
90. Bélanger, S.; Esteves, P.; Clermont, I.; Jean, M.; Belzile, F. Genotyping-by-sequencing on pooled samples and its use in measuring segregation bias during the course of androgenesis in barley. Plant Genome 2016, 9, 1-13. [CrossRef]

91. Hayward, M.D.; Olesen, A.; Due, I.K.; Jenkins, R.; Morris, P. Segregation of isozyme marker loci amongst androgenetic plants of Lolium perenne L. Plant Breed. 1990, 104, 68-71. [CrossRef]

92. Kindiger, B. Generation of paternal dihaploids in tall fescue. Grassl. Sci. 2016, 62, 1-5. [CrossRef]

93. Kindiger, B. Sampling the genetic diversity of tall fescue utilizing gamete selection. In Genetic Diversity in Plants; Caliskan, M., Ed.; InTech: Rijeka, Croatia, 2012; pp. 271-284.

94. Ravi, M.; Chan, S.W. Centromere-mediated generation of haploid plants. In Plant Centromere Biology; Jiang, J., Birchler, J.A., Eds.; John Wiley \& Sons, Inc.: Hoboken, NJ, USA, 2013; pp. 169-181.

95. Kelliher, T.; Starr, D.; Wang, W.; Mccuiston, J.; Zhong, H.; Nuccio, M.L.; Martin, B. Maternal haploids are preferentially induced by CENH3-tailswap transgenic complementation in maize. Front. Plant Sci. 2016, 7, 1-11. [CrossRef] [PubMed]

96. Karimi-Ashtiyani, R.; Ishii, T.; Niessen, M.; Stein, N.; Heckmann, S.; Gurushidze, M.; Banaei-Moghaddam, A.M.; Fuchs, J.; Schubert, V.; Koch, K.; et al. Point mutation impairs centromeric CENH3 loading and induces haploid plants. Proc. Natl. Acad. Sci. USA 2015, 112, 11211-11216. [CrossRef] [PubMed]

97. Charlesworth, D.; Willis, J.H. The genetics of inbreeding depression. Nat. Rev. Genet. 2009, 10, $783-796$. [CrossRef] [PubMed]

98. Wilde, K.; Burger, H.; Prigge, V.; Presterl, T.; Schmidt, W.; Ouzunova, M.; Geiger, H.H. Testcross performance of doubled-haploid lines developed from European flint maize landraces. Plant Breed. 2010, 129, 181-185. [CrossRef]

99. Strigens, A.; Schipprack, W.; Reif, J.C.; Melchinger, A.E. Unlocking the genetic diversity of maize landraces with doubled haploids opens new avenues for breeding. PLoS ONE 2013, 8, e57234. [CrossRef] [PubMed]

100. Jacquard, C.; Nolin, F.; Hécart, C.; Grauda, D.; Rashal, I.; Dhondt-Cordelier, S.; Sangwan, R.S.; Devaux, P.; Mazeyrat-Gourbeyre, F.; Clément, C. Microspore embryogenesis and programmed cell death in barley: Effects of copper on albinism in recalcitrant cultivars. Plant Cell Rep. 2009, 28, 1329-1339. [CrossRef] [PubMed]

101. Larsen, E.T.; Tuvesson, I.K.; Andersen, S.B. Nuclear genes affecting percentage of green plants in barley (Hordeum vulgare L.) anther culture. Theor. Appl. Genet. 1991, 82, 417-420. [CrossRef] [PubMed]

102. Gurushidze, M.; Hensel, G.; Hiekel, S.; Schedel, S.; Valkov, V.; Kumlehn, J. True-breeding targeted gene knock-out in barley using designer TALE-nuclease in haploid cells. PLoS ONE 2014, 9, 1-9. [CrossRef] [PubMed]

103. Giri, C.C.; Praveena, M. In vitro regeneration, somatic hybridization and genetic transformation studies: An appraisal on biotechnological interventions in grasses. Plant Cell Tissue Organ Cult. 2014, 120, 843-860. [CrossRef]

104. Eudes, F.; Shim, Y.S.; Jiang, F. Engineering the haploid genome of microspores. Biocatal. Agric. Biotechnol. 2014, 3, 20-23. [CrossRef]

105. Chugh, A.; Amundsen, E.; Eudes, F. Translocation of cell-penetrating peptides and delivery of their cargoes in triticale microspores. Plant Cell Rep. 2009, 28, 801-810. [CrossRef] [PubMed]

106. Bilichak, A.; Luu, J.; Eudes, F. Intracellular delivery of fluorescent protein into viable wheat microspores using cationic peptides. Front. Plant Sci. 2015, 6, 666. [CrossRef] [PubMed]

107. Kumar, V.; Jain, M. The CRISPR-Cas system for plant genome editing: Advances and opportunities. J. Exp. Bot. 2015, 66, 47-57. [CrossRef] [PubMed]

108. Maluszynski, M.; Ahloowalia, B.S.; Sigurbjörnsson, B. Application of in vivo and in vitro mutation techniques for crop improvement. Euphytica 1995, 85, 303-315. [CrossRef]

109. Szarejko, I.; Forster, B.P. Doubled haploidy and induced mutation. Euphytica 2007, 158, 359-370. [CrossRef]

110. Kurowska, M.; Labocha-Pawłowska, A.; Gnizda, D.; Maluszynski, M.; Szarejko, I. Molecular analysis of point mutations in a barley genome exposed to MNU and Gamma rays. Mutat. Res. 2012, 738-739, 52-70. [CrossRef] [PubMed]

111. Lübberstedt, T.; Frei, U.K. Application of doubled haploids for target gene fixation in backcross programmes of maize. Plant Breed. 2012, 131, 449-452. [CrossRef] 
112. Delourme, R.; Falentin, C.; Fomeju, B.F.; Boillot, M.; Lassalle, G.; André, I.; Duarte, J.; Gauthier, V.; Lucante, N.; Marty, A.; et al. High-density SNP-based genetic map development and linkage disequilibrium assessment in Brassica napus L. BMC Genom. 2013, 14, 120. [CrossRef] [PubMed]

113. Cabral, A.L.; Jordan, M.C.; McCartney, C.A.; You, F.M.; Humphreys, D.G.; MacLachlan, R.; Pozniak, C.J. Identification of candidate genes, regions and markers for pre-harvest sprouting resistance in wheat (Triticum aestivum L.). BMC Plant Biol. 2014, 14, 340. [CrossRef] [PubMed]

114. Sannemann, W.; Huang, B.E.; Mathew, B.; Léon, J. Multi-parent advanced generation inter-cross in barley: High-resolution quantitative trait locus mapping for flowering time as a proof of concept. Mol. Breed. 2015, 35, 86. [CrossRef]

115. Bert, P.F.; Charmet, G.; Sourdille, P.; Hayward, M.D.; Balfourier, F. A high-density molecular map for ryegrass (Lolium perenne) using AFLP markers. Theor. Appl. Genet. 1999, 99, 445-452. [CrossRef] [PubMed]

116. Jones, E.S.; Mahoney, N.L.; Hayward, M.D.; Armstead, I.P.; Jones, J.G.; Humphreys, M.O.; King, I.P.; Kishida, T.; Yamada, T.; Balfourier, F.; et al. An enhanced molecular marker based genetic map of perennial ryegrass (Lolium perenne) reveals comparative relationships with other Poaceae genomes. Genome 2002, 45, 282-295. [CrossRef] [PubMed]

117. Guo, B.; Wang, D.; Guo, Z.; Beavis, W.D. Family-based association mapping in crop species. Theor. Appl. Genet. 2013, 126, 1419-1430. [CrossRef] [PubMed]

118. King, J.; Armstead, I.P.; Donnison, I.S.; Harper, J.A.; Roberts, L.A.; Thomas, H.; Ougham, H.; Thomas, A.; Huang, L.; King, I.P. Introgression mapping in the grasses. Chromosom. Res. 2007, 15, 105-113. [CrossRef] [PubMed]

119. Humphreys, M.W.; Gasior, D.; Lesniewska-Bocianowska, A.; Zwierzykowski, Z.; Rapacz, M. Androgenesis as a means of dissecting complex genetic and physiological controls: Selecting useful gene combinations for breeding freezing tolerant grasses. Euphytica 2007, 158, 337-345. [CrossRef]

120. Petersen, G.; Johansen, B.; Seberg, O. PCR and sequencing from a single pollen grain. Plant Mol. Biol. 1996, 31, 189-191. [CrossRef] [PubMed]

121. Dreissig, S.; Fuchs, J.; Cápal, P.; Kettles, N.; Byrne, E.; Houben, A. Measuring meiotic crossovers via multi-locus genotyping of single pollen grains in barley. PLoS ONE 2015, 10, 1-10. [CrossRef] [PubMed]

122. Chen, P.H.; Pan, Y.B.; Chen, R.K. High-throughput procedure for single pollen grain collection and polymerase chain reaction in plants. J. Integr. Plant Biol. 2008, 50, 375-383. [CrossRef] [PubMed]

123. Goff, S.A. Tansley review-A unifying theory for general multigenic heterosis: Energy efficiency, protein metabolism, and implications for molecular breeding. New Phytol. 2011, 189, 923-937. [CrossRef] [PubMed]

124. Hallauer, A.R.; Carena, M.J.; Filho, J.B.M. Inbreeding. In Quantitative Genetics in Maize Breeding; Hallauer, A.R., Carena, M.J., Filho, J.B.M., Eds.; Springer: New York, NY, USA, 2010; pp. 425-475.

125. Geiger, H.H.; Miedaner, T. Rye breeding. In Cereals; Carena, M.J., Ed.; Springer: New York, NY, USA, 2009; pp. 157-181.

126. Brummer, E.C. Capturing heterosis in forage crop cultivar development. Crop Sci. 1999, 39, $943-954$. [CrossRef]

127. Riddle, N.C.; Birchler, J.A. Comparative analysis of inbred and hybrid maize at the diploid and tetraploid levels. Theor. Appl. Genet. 2008, 116, 563-576. [CrossRef] [PubMed]

128. Kopecky, D.; Lukaszewski, A.J.; Gibeault, V. Reduction of ploidy level by androgenesis in intergenic Lolium-Festuca hybrids for turf grass breeding. Crop Sci. 2005, 45, 274-281.

129. Yang, B.; Thorogood, D.; Armstead, I.P.; Franklin, F.C.H.; Barth, S. Identification of genes expressed during the self-incompatibility response in perennial ryegrass (Lolium perenne L.). Plant Mol. Biol. 2009, 70, 709-723. [CrossRef] [PubMed]

130. Klaas, M.; Yang, B.; Bosch, M.; Thorogood, D.; Manzanares, C.; Armstead, I.P.; Franklin, F.C.H.; Barth, S. Progress towards elucidating the mechanisms of self-incompatibility in the grasses: Further insights from studies in Lolium. Ann. Bot. 2011, 108, 677-685. [CrossRef] [PubMed]

131. Manzanares, C.; Barth, S.; Thorogood, D.; Byrne, S.L.; Yates, S.; Czaban, A.; Asp, T.; Yang, B.; Studer, B. A gene encoding a DUF247 domain protein cosegregates with the $S$ self-incompatibility locus in perennial ryegrass. Mol. Biol. Evol. 2016, 33, 870-884. [CrossRef] [PubMed]

132. Islam, M.S.; Studer, B.; Møller, I.M.; Asp, T. Genetics and biology of cytoplasmic male sterility and its applications in forage and turf grass breeding. Plant Breed. 2014, 133, 299-312. [CrossRef] 
133. Pembleton, L.W.; Shinozuka, H.; Wang, J.; Spangenberg, G.C.; Forster, J.W.; Cogan, N.O.I. Design of an F1 hybrid breeding strategy for ryegrasses based on selection of self-incompatibility locus-specific alleles. Front. Plant Sci. 2015, 6, 764. [CrossRef] [PubMed]

134. Do Canto, J.; Studer, B.; Lubberstedt, T. Overcoming self-incompatibility in grasses: A pathway to hybrid breeding. Theor. Appl. Genet. 2016, 129, 1815-1829. [CrossRef] [PubMed]

135. Posselt, U.K. Heterosis in grasses. Czech J. Genet. Plant Breed. 2003, 39, 48-53.

(C) 2016 by the authors; licensee MDPI, Basel, Switzerland. This article is an open access article distributed under the terms and conditions of the Creative Commons Attribution (CC-BY) license (http://creativecommons.org/licenses/by/4.0/). 